\title{
PROCESSING POSSESSIVES IN SIMULTANE- OUS INTERPRETING FROM ENGLISH TO POLISH
}

\author{
KATARZYNA STACHOWIAK-SZYMCZAK AND BERGLJOT BEHRENS \\ University of Warsaw \\ University of Oslo
}

ABSTRAC T

The present paper reports on an experiment in which the use of possessives is investigated in an interpreting task from English to Polish. The English possessive determiner system is neutral with respect to the syntactic position of the antecedent possessor, while Polish distinguishes lexically between locally bound - i.e. reflexive - and non-reflexive possessive modifiers. The interpreter therefore has to 'compute' mentally the syntactic position of the antecedent possessor in order to make the correct choice in Polish as the target language. The study shows that this is cognitively a very demanding task in simultaneous interpreting, as many errors as well as self-corrections occur. The study furthermore shows that interpreters adapt their language to their audience, and adequate omissions, as well as correct form of the possessive occur more often when they have a group of engineers in mind than when they interpret for language specialists. We understand this to mean that the cognitive complexity of solving the crosslinguistic asymmetry in the possessive system causes more errors when the interpreter stays closer to the source text in speaking to language specialists.

\section{[1] INTRODUCTION}

The present study investigates linguistic effects in interpreting English to Polish. The study is a contribution to a larger project (SPROSS) investigating learner (cognitive) effects of an asymmetric grammatical feature of European languages: the system of possessives. ${ }^{1}$

Most West-European languages do not make a lexical distinction between reflexive and non-reflexive possessives. This means that a brief example like Peter liked his car, viewed in isolation, is ambiguous with respect to whose car is referred to: Peter's own car or somebody else's, and likewise for its equivalents

[1] See https://www.hf.uio.no/ilos/english/research/projects/language-as-product-and-process/index.html 
in e.g. German, or a Roman language like French, Spanish or Italian. Some languages that also have a determiner system, such as the Scandinavian languages, make a distinction: If Peter (the subject of the clause) is the owner, the reflexive possessive determiner (SIN) is used (within the same clause), if he is not, the non-reflexive possessive hans 'his' is the only correct choice.

While East-European languages are recognised not to have proper determiners, they do distinguish between reflexives and non-reflexives, and would make the same distinction as in the Scandinavian languages to express the possible relationships:

(1) a. Peter lubi swój samochód.

'Peter likes his (own) car.' (The reflexive swój points back to Peter, the syntactic subject of the clause.)

b. Peter lubi jego samochód.

'Peter likes his car.' (The non-reflexive possessive jego points to somebody else's car.)

The broader context will normally contribute to the disambiguation of the English possessive. In translation and interpreting, the disambiguation is central for the choice of possessive marker in Polish, and misunderstanding may occur if the wrong choice is made, or it is dropped altogether. Previous studies of advanced learners of a foreign language which makes the distinction but whose mother tongue does not, have shown that acquiring native-like competence is extremely difficult (see e.g. Helland 2017 for a study on French learners of Norwegian). One hypothesis proposed to explain this is that the 'double' system (like the Scandinavian languages and Polish) is extremely complex: not only are there two forms, but correct choice involves a number of morphological, syntactic and semantic factors (for an overview, see Fabricius-Hansen et al. 2017).

Although interpreters generally have native-like competence in their two working languages, the question we raise here is whether the already extremely complex task of interpreting in any way affects the processing of possessives when the systems are asymmetric. Our question is motivated by the cognitive complexity of the two tasks. Interpreting involves the processing of dynamic, interlingual, linguistic transfer of meaning, style, register and intent. In the process of transferring information from English to Polish, for example, correct choice involves deciding whether the possessive determiner in the source language has a reflexive or a non-reflexive interpretation, depending on the syntactic position of the possessor (its antecedent) in the target language.

Our study investigates possible grammatical transfer in conference interpreters interpreting for different target audiences (sections 3 and 4 give our 
motivation for this division). More specifically, we primarily ask whether there is a priming effect related to possessives in simultaneous interpreting. Secondly, we ask if different briefings affect this potential priming, one group interpreting for (Polish) language specialists, the other for a group of engineers. As an addition, we consider independent judges' quality ratings of the interpreters' production and whether the ratings in any way correlate with grammatical correctness.

The paper is structured as follows: First, the possessive systems of English and Polish are delineated. Secondly, the complexity of interpreting is discussed together with its perceived quality, and the rationale for the study. Finally, the experimental section presents the study itself, followed by a discussion of the results and implications for future research and teaching.

\section{[2] THE POSSESSIVE SYSTEMS IN ENGLISH AND POLISH}

As the study tests interpreters working with English and Polish, it seems indispensable to delineate the differences in the possessive systems of these two languages. English weak possessives (my, your, his, her, our, their) are functional equivalents of articles playing the role of definite determiners. Weak possessive pronouns and definite articles are mutually exclusive in reference to what they determine, yet in many contexts they are grammatically and semantically substitutable. For instance, in the following sentence the possessor's (i.e. Lily's) car can be both described as her and preceded by the:

(2) Lily looked in the rear mirror of her/the car.

Importantly, the presence of either a possessive pronoun or an article determining a noun is necessary for a correct grammatical structure. This is not the case in Polish, which does not have the functional equivalent of the definite article and often allows the omission of possessives.

The Polish language distinguishes between two types of possessives: the personal, non-reflexive possessive pronoun (mój 'my', twój 'your' (sg.), jego 'his', jej 'her', nasz 'our', wasz 'your (pl.), ich 'their') and the reflexive (swój), presented in Table 1 below.

For the clarity of exposition, in the remainder of the present paper we shall call the reflexive, locally bound, possessive 'the reflexive', while the personal possessive pronouns, non-locally bound, will be designated 'the non-reflexive'. 


\begin{tabular}{|c|c|c|}
\hline $\begin{array}{l}\text { Per- } \\
\text { son }\end{array}$ & Non-reflexive possessive & $\begin{array}{l}\text { Reflexive posses- } \\
\text { sive }\end{array}$ \\
\hline $1^{\text {st }} \mathrm{sg}$ & mój (m.)/moja (f.)/ moje (n.)* & \\
\hline $2^{\text {nd }} \mathrm{sg}$. & twój (m.)/ twoja (f.)/ twoje (n.)* & \\
\hline $3^{\text {rd }} \mathrm{sg}$. & $\begin{array}{c}\text { jej (for fem. possessor) } \\
\text { jego (for masc./neuter possessor) }\end{array}$ & swój (m.)/ swoja (f.)/ \\
\hline $1^{\text {st }} \mathrm{pl}$ & nasz (m.)/ nasza (f.)/ nasze (n.)* & \\
\hline $2^{\text {nd }} \mathrm{pl}$. & wasz (m.)/ wasza (f.)/wasze (n.)* & \\
\hline $3^{\text {rd }} \mathrm{pl}$. & $i c h$ & \\
\hline
\end{tabular}

TABle 1: The Polish system of possessives; *m., f. and n. refer to different masculine, feminine and neuter forms depending on the gender of the possessee (irrespective of two distinct forms for the 3rd person sg. dependent on the gender of the possessor).

Non-reflexive possessives are used when the owner (possessor) is not the same as the subject of the sentence, as in (3):

(3) Bardzo lubię wasze dzieci.

'I like your children very much.'

This is also the choice in subordinate clauses in which the unexpressed subject co-refers with the subject of the main clause:

(4) Opiekujac się ich psem, Anna zdecydowała, że też adoptuje jakiegoś zwierzaka. 'While taking care of their dog, Anna decided to adopt a pet as well.'

In contrast, the reflexives, swój (m.), swoja (f.), swoje (n. and pl.) are used when they co-refer with the subject of the clause they occur in. The reflexives take endings in accordance with the gender, number and case of the possessee but are neutral as to the grammatical person, number and gender of the possessor. Thus, it is correct to use the reflexive swój as in (5), indicating that the subject (implicit in Polish) is painting his own flat. ${ }^{2}$

$\mathrm{He}_{\mathrm{i}}$ is painting his $\mathrm{s}_{\mathrm{i}}$ flat.

Maluje swoje $_{i}$ mieszkanie.

This is what has been termed local binding. The non-reflexive possessive jego in the same context would indicate a favour the subject does to someone else by

[2] $i$ is an index showing the co-reference. 
painting this other person's house. Swój is also the only explicit option in (6), as it would be impossible for Jola to have devoted someone else's life to art (similarly to cases of selling personal property, abstract terms related to emotions, etc.).

\section{(6) Jola poświęciła swoje życie sztuce.}

'Jola devoted her life to art.

Similar to other Slavic languages, e.g. Russian, the possessives (whether reflexive or non-reflexive) are frequently subject to omission, as the ownership is very often inferable from context. In other words, when context is clear, omitting a possessive is highly acceptable from a grammatical point of view. In reference to Russian (and similarly to Polish), Ioffe (1985) proposes that null possessives are marked with a certain assumption that the possessor is in direct relation with the possessee. In more general terms, the possessive would be most frequently dropped when the possessee clearly and unambiguously belongs to the possessor (see a similar description in Comer 2009). This clarity is usually context-driven, as in (6) above, where Jola devotes her own life to art, but may be also logically, culturally, gender or socially bound, etc. as in (7), where the reader would assume that the teddy belongs to the little girl.

Mała dziewczynka przytuliła misia.

'The little girl hugged teddy bear.'

In contrast to Polish, English possessives may not be dropped in most cases, while they are sometimes replaced by the definite article.

The main difficulty that arises for a Polish learner (and interpreter) of English is rooted in the asymmetry of the English and Polish systems: While the interpretation of a possessive is pragmatics-driven in English, it is grammardriven in Polish, and this may cause confusion. In Polish, local binding always demands the selection of a reflexive, rather than the non-reflexive pronoun, as in (8), where their is locally bound to leaders.

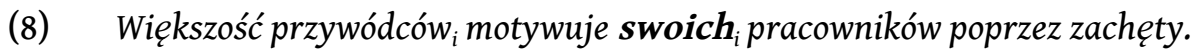

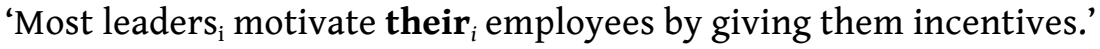

By the same token, in the course of translating or interpreting pronouns from English into Polish, the interpreter/translator usually decides upon selecting a 
reflexive or a non-reflexive possessive based on the local/non-local binding distinction ${ }^{3}$.

In interpreting from English into Polish, the need for selection means that occasionally pronouns with local binding can be erroneously rendered as nonreflexive possessive modifiers (mój/ twój/ jego/jej/ nasz/ wasz/ ich) instead of the reflexive (swój). ${ }^{4}$ In the process of learning, English possessive determiners are usually presented to students as direct equivalents of the non-reflexive possessives (mój/ twój/ jego/ jej/ nasz/ wasz/ ich), the reflexive as a direct equivalent often being neglected. For this reason, interpreting and translating possessive pronouns with local binding may be subject to negative transfer. Also, due to the complexity of interpreting itself, the cross-linguistic transfer of possessives might turn out to be problematic in interpreting. Finally, there seems to be a tendency to overuse non-reflexive possessives in Polish, as opposed to the reflexive swój, which is prescriptively ill-founded. ${ }^{5}$

In both learning and interpreting, erroneous rendering may lead to misunderstanding. In a very simplified scenario typical of non-advanced learners, the interlocutor would be misinformed about who the possessor is. In turn, interpreters usually speak for native audiences when working into Polish and using an incorrect pronoun may be deemed unprofessional.

[3] THE COMPLEXITy OF SimULTANEOUS INTERPRETING

Simultaneous interpreting includes concurrent listening and speaking in two languages, in addition to executive processing as well as a number of other subprocesses (Lederer 1981; Gile 2009). Recent studies (e.g. Seeber 2017) add to the complexity by including visual and motor processing in the simultaneous interpreting task.

Most importantly, simultaneous interpreting involves bilingual language activation and requires that the interpreter can keep a balance between the appropriate levels of this activation of the two (source and target) languages. Unlike in many other bilingual scenarios, interpreters do not suppress one language while the other is active. Even in the consecutive mode, where production follows listening, interpreters have been observed to be characterised by

[3] Unless there are other factors influencing the choice, such as context, or intent, e.g. the willingness to underline that the possessee belongs to the possessor, for instance in: I will take care of my (own) child on my own, and it's not for you to interfere, where the narrator's intent is to emphasize that the child is indeed his or her responsibility. In such cases (equivalent in Polish), both possessives and reflexives would be prescriptively correct, while in general the reflexive is the grammatically determined pronoun of choice.

[4] Unless otherwise indicated, swój (m.sg.nominative) represents the whole set of inflected forms of the reflexive possessive; and likewise for mój, twoj, nasz, wasz.

[5] According to personal communication with the Polish Language Centre (Centrum Języka Polskiego). 
non-selective language access, and to take notes in two (or even three) working languages (de Groot and Christoffels 2006).

By the same token, interpreters are prone to inter-lingual priming and transfer. The constant balancing between language activation and suppression calls for extremely good focus, attention management and monitoring, exerting great cognitive load on the interpreter's mind. (Hervais-Adelman et al. 2014). At the same time, multitasking itself under extreme time pressure, especially in the simultaneous mode, adds difficulty to the task. In consequence, one of the sub-processes (e.g. production) of interpreting may be (temporarily) mismanaged, resulting in target text production with elements of the source language.

Linguistic transfer can be of a syntactic nature, as reported by Hartsuiker et al. (2004), who observed that bilinguals use Spanish-like syntactic structures in English, having heard a Spanish sentence. It may be semantic, as reported in Aparicio and Lavaur (2018), who found semantic priming in trilinguals conducting a translation task. Or it may be phonological: Cho and Park (2006) observed phonological transfer of (mother tongue) Korean features in English, during interpreting. The reverse has also been observed: Stachowiak (2018) reported prosodic priming in interpreters working from English into their (mother tongue) Polish.

At the same time, interpreters are expected to be resistant to inter-lingual priming and transfer. The bidirectional interpreter shall be able to demonstrate that he or she possesses, somehow difficult to delineate, proficient linguistic skills and competences in both languages. In other words, they 'shall demonstrate the required linguistic ability in their working languages based on nationally or professionally accepted standards of language proficiency' (ISO 18841:2018). Although determining these standards has raised discussion, it is vital, for the purpose of the present paper, to underline the importance of syntactic and grammatical competence of the simultaneous interpreter, including the applied knowledge of possessives in a broad sense which the study presented here is about.

According to Pöchhacker (2001: 421) and Bühler (1986), interpreting quality is primarily related to the accurate rendition of the source text. At the same time, it also requires adequate target text expression, equivalent intended effect and successful communicative interaction. All these elements lead to [good] interpreting service and product (see Fig. 1). 


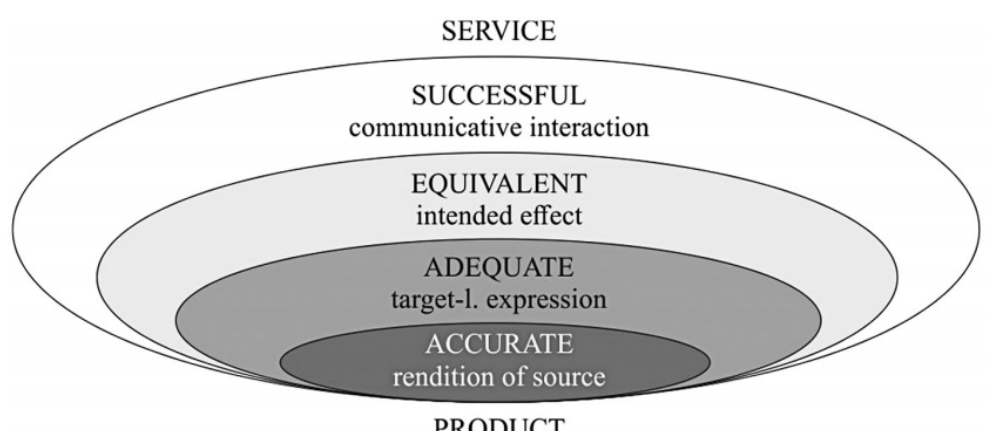

FIGURE 1: Quality standards in interpreting (Adapted from Pöchhacker 2001: 413)

Central for quality assessment, then, is accurate rendition of the source. We would therefore assume that (in)correct selection of reflexive and nonreflexive possessives affects the quality raters' assessment.

[4] THE EXPERIMENTAL STUDY

\section{[4.1] Aim and research questions}

The study is aimed at providing answers to the following research questions:

1. Will there be cross-linguistic transfer of possessives observable in the simultaneous interpretation of possessives from English into Polish?

The question is rooted in research on transfer discussed in the theoretical part of this article. We aim to verify whether English possessive determiners will be erroneously rendered as non-reflexives in Polish.

2. Will the correctness of interpreting possessives or other pronouns/determiners into Polish be associated with the particular target group (i.e. depending on condition: briefing 1 vs. briefing 2)?

The literature on bilingual communication has demonstrated that speakers adapt their speech to the interlocutor (see Section 3 above). In view of the fact that interpreters in the simultaneous mode talk to an audience and do not engage in real bi-directional dialogue, do they still adjust their speech according to a projected interlocutor? And if they do, will it affect grammatical correctness? We assume that the closer the accuracy of form, the likelier it is that grammatical transfer, and consequently more errors, will occur in the selection of the correct possessive (reflexive or non-reflexive). 
3. Can cross-linguistic transfer of possessives be associated with the subjectively perceived level of correctness rated by independent judges?

We mentioned in Section 3 that there is some controversy with respect to a correlation between grammatical correctness and subjectively perceived interpreting quality. Moreover, according to Kurz (2001), interpreters or interpreting teachers might have different expectations and perceptions of the target text than the actual audience or target client. With 40 independent judges assessing the interpreters' production in our experiment, we consider the validity of the disparate claims in the literature.

\section{[4.2] Study design}

This is a typical between-subject design study, where two groups of participants are compared in two conditions (briefing 1 vs. briefing 2). Therefore, target group, i.e. the type of audience (Polish language specialists - briefing 1 vs. engineers - briefing 2) constitutes the main independent variable in this study.

Conditions, i.e. briefings, differed in instructions delivered to the participants:

Briefing 1 included the following instructions: 'You are interpreting at a leadership and work management course organised within a larger international conference. An English coach will be speaking to your audience, a group specialising in Polish language studies. Interpret the text from English into Polish.'

Briefing 2 included the following instructions: 'You are interpreting at a leadership and work management course organised within a larger international conference. An English coach will be speaking to your audience, a group specialising in mechanical engineering. Interpret the text from English into Polish.'

The dependent variables included in the experiment were as follows:

- Possessive interpreting accuracy: number of correctly rendered possessives in the target product,

- Degree of target text quality rated by independent judges.

\section{[4.3] Participants}

The study sample included 40 professional interpreters ( 21 males, 19 females). The inclusion criterion was having worked as a simultaneous interpreter for at least 100 working days (understood as 100 days during which an interpreter 
worked in any mode of interpreting, irrespective of whether an assignment lasted 3 or 8 hours). ${ }^{6}$

All the participants had Polish as A language in their language combination (i.e. their mother tongue) and English as their B language, i.e. their active language (AIIC 2016). ${ }^{7}$ All the professional interpreters who participated in the study were bidirectional interpreters, in other words: they interpret from their language A into B and vice versa on a daily basis. Detailed information on the interpreters is provided in Table 3.

\begin{tabular}{cc}
\hline & Interpreters \\
\hline Age [years] & $M=31.8 ; S D=6.14$ \\
Experience [years] & $M=8.1 ; S D=5.23$ \\
\hline
\end{tabular}

TABLE 3: Mean age and experience in two experimental groups

\section{[4.4] Materials}

In the experiment, each participant simultaneously interpreted a speech from English into Polish. The speeches were both about leadership and work management and similar in structure and length. To achieve maximum ecological validity, the texts were prepared as natural, motivational speeches by an external coach, then verified by the authors of the study and then recorded by a female, by means of the Praat software developed by Paul Boersma and Vincent van Heuven (2001), the rationale being to have a semi-controlled, yet natural speech. Each speech lasted ten and a half minutes. Speech 1 was rendered at a pace of 91.9 words per minute (wpm) and Speech 2: $93.1 \mathrm{wpm}$.

Out of each text, 40 possessives were selected for the subsequent analysis. 38 of them were locally bound in semantically and grammatically unambiguous sentences. A correct rendition of each of the 38 locally bound possessives in Polish would require the use of a reflexive or pronoun omission (see: Section 2). The texts are included in the Appendix.

Finally, the independent judges were given a questionnaire related to the lexical, grammatical, syntactic and phonological correctness of the target text.

[6] This criterion was based on the fact that major professional interpreter organizations such as the International Association for Conference Interpreting (AIIC) require more than 100 working days (150 in the case of AIIC, 100 e.g. in the case of the Polish Association of Conference Interpreters) from applicants for membership.

[7] see: https://aiic.net/page/4004/what-are-working-languages-to-a-conference-interpreter/lang/1 


\section{[4.5] Software and apparatus}

The Audacity 2.0.5. software was used to record the interpretations for further analysis of number interpreting accuracy. IBM SPSS Statistics 24 software was used to perform inferential statistics tests.

\section{[4.6] Procedure}

The experiment took place in a room where the interpreter sat inside an interpreting booth. The participants were equipped with a microphone and a headset. At the beginning of the experimental session the participants were informed about the procedures of the experiment. Prior to the interpretation, they were asked to sign an informed consent form specifying that the project involved the cognitive aspects of simultaneous interpreting. Next, they were asked to interpret a speech in the simultaneous mode. There were two different experimental conditions, referred to in the present paper as briefing 1 and briefing 2. The speeches (speech 1 and speech 2) were counterbalanced across the conditions, i.e. some participants interpreted Speech 1 according to Briefing 1 (for language specialists) and Speech 2 according to Briefing 2 (for engineers) and some - the other way round. The study was followed by a debriefing session to inform the participants in detail about study objectives and research questions.

Finally, the interpreting output was played to 40 independent judges (where each recording was rated by five judges, and the order of presentation was counterbalanced across the judges) to rate the quality of the output according to a 7-point Likert scale. Each judge could listen to each output more than once. The judges were randomly selected out of the population aged 28-60 years and approached by personal contact. They were also tested for the level of their Polish and English language skills to verify if there was any association between their skills and their scores.

\section{[4.7] Data Analysis}

First, the interpreting accuracy was analysed based on a simple self-designed grading scale. According to this scale, 1 point was given for each correct rendition of a possessive (which meant selecting the correct possessive or omitting the possessive in Polish) and 0 points - for an incorrect rendition. 0.5 points was given for self-correction. For instance, 0 points was given when the interpreter resorted to a possessive pronoun when a reflexive should be produced, which resulted in a semantically incorrect sentence, as in the following example, where the solutions in b. and c. are both correct translations and given 1 
point, while d. would incorrectly refer to somebody else's hair, and consequently is given 0 points:
(9) a. John had his hair trimmed.
(Original sentence)
b. John obcią swoje włosy.
(Reflexive possessive)
c. John obcią włosy.
(Omission of possessive)
d. John obciął jego włosy.
(Non-reflexive possessive)

Importantly, not every single target sentence was as a linear, exact equivalent of the original (English) one. In many cases, a single source sentence was split into two in interpreting. That is because simultaneous interpreters derive and form meaning based on context and general sense, rather than rendering texts in a verbum pro verbo manner. Clearly, testing or analysing interpreting in a sentence-by-sentence experiment would be ecologically invalid, if not impossible. By the same token, in this study, interpreters would resort to different grammatical structures and not every pronoun was found (if at all) in the position corresponding to the original one. For the analysis, therefore, we divided the original text and the target texts into corresponding fragments we called 'ideas of interest', after Holmqvist et al (2015). In other words, we verified which fragments of the target texts corresponded to the source text fragments we were interested in. Each idea of interest included a possessive in the original text (in fact, often constituting a phrase or a sentence), e.g. as in (10):

(10) a. [04:53]: Authentic leaders are not afraid to expose their weaknesses ... [05:08] (the English source)

b. [04:57]: Co robiq autentyczni przywódcy? Pokazują swoje słabości. Nie bojq się tego robić. [05:15] (reflexive possessive)

'What do authentic leaders do? They show their weaknesses. They are not afraid to do so.'

The English clause forms one idea of interest, lasting 15 seconds, and is expressed as three sentences in Polish, where the central sentence constitutes the key element we were interested in. The correctness of each single idea of interest in the target texts was rated in a manner explained above. The maximum score for each text was 40 points. We then calculated the judges' ratings.

We also calculated the chi-square coefficient to test correlations between the type of briefing and the interpreters' accuracy score, as well as between the type of briefing and the judges' correctness score. $\mathrm{p}<.05$ was considered statistically significant. 


\section{[4.8] Results}

The mean number of possessives (whether reflexive or not) used was equal to $19.7(S D=12.5)$ under briefing 1 and $17.5(S D=11)$ under briefing 2 . Within the areas of interest that were identified, the interpreters used 478 possessives when interpreting for language specialists and 334 possessives when interpreting for engineers (Figure 2 shows these numbers, together with the number of omissions). Paired-samples t-tests showed that these differences were statistically insignificant $(p>.05)$. On the other hand, another Paired-samples t-test produced a statistically significant result $(p=.022)$ for the difference in the number of omissions that was higher under briefing $2(M=12.55 ; S D=5.5)$ than in the briefing 1 group $(M=6.5 ; S D=4.5)$. Sections 4.8 .1 and 4.8.2 present details on the number of possessive use and its accuracy.

\section{Cross-linguistic transfer of possessives}

Figure 2 illustrates the number of times an English possessive (his/her/their) was interpreted correctly (as swój/swoja/swoje), omitted (which also is a correct rendition into Polish) or interpreted incorrectly (as jego/jej/ich) into Polish. The number of self-corrections is also included.

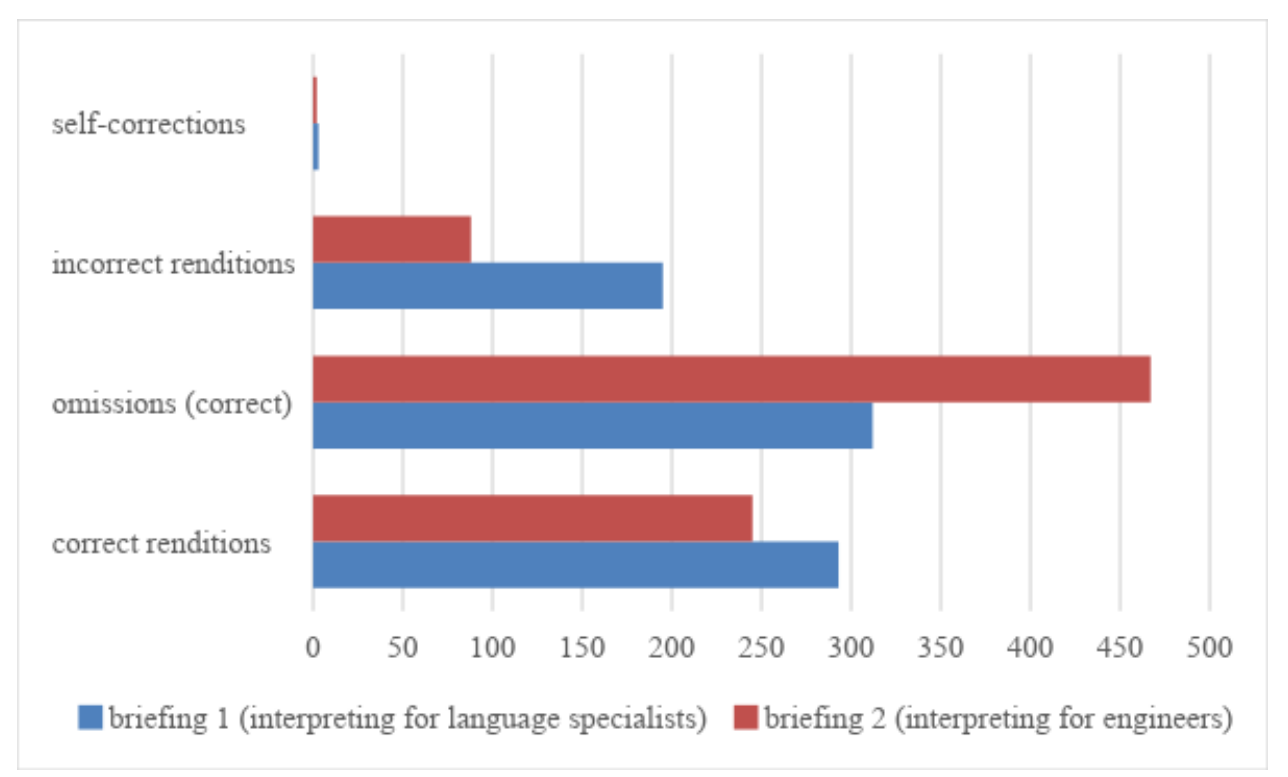

FIGURE 2: Number of correct possessive renditions (including omissions), incorrect renditions and self-corrections. 
Possessive Interpreting Accuracy

While the results above relate to overall correctness, Figure 3 below presents the accuracy of interpreting English possessives into Polish, on a scale from 0 to 40 (see Section 4.7). The accuracy is displayed for two briefings: interpreting 'for language specialists' (briefing 1) and 'for engineers' (briefing 2).

There was also an observable association between the type of briefing (hence the type of 'audience': Polish language specialists vs. engineers) and the possessive interpreting accuracy score. More specifically, the correlation between the type of briefing and the interpreter's accuracy score reached statistical significance for:

- briefing $1(\chi(1)=0.332, p=.0251)$,

- $\quad$ briefing $2(\chi(1)=0.421, p=.0271)$.

At the same time, paired-samples t-tests further showed that in the briefing 2 group $(M=35.65 ; S D=6.13)$ the accuracy rates were significantly $(p=.016)$ higher than in the briefing 1 group $(M=30.33 ; S D=4.73)$.

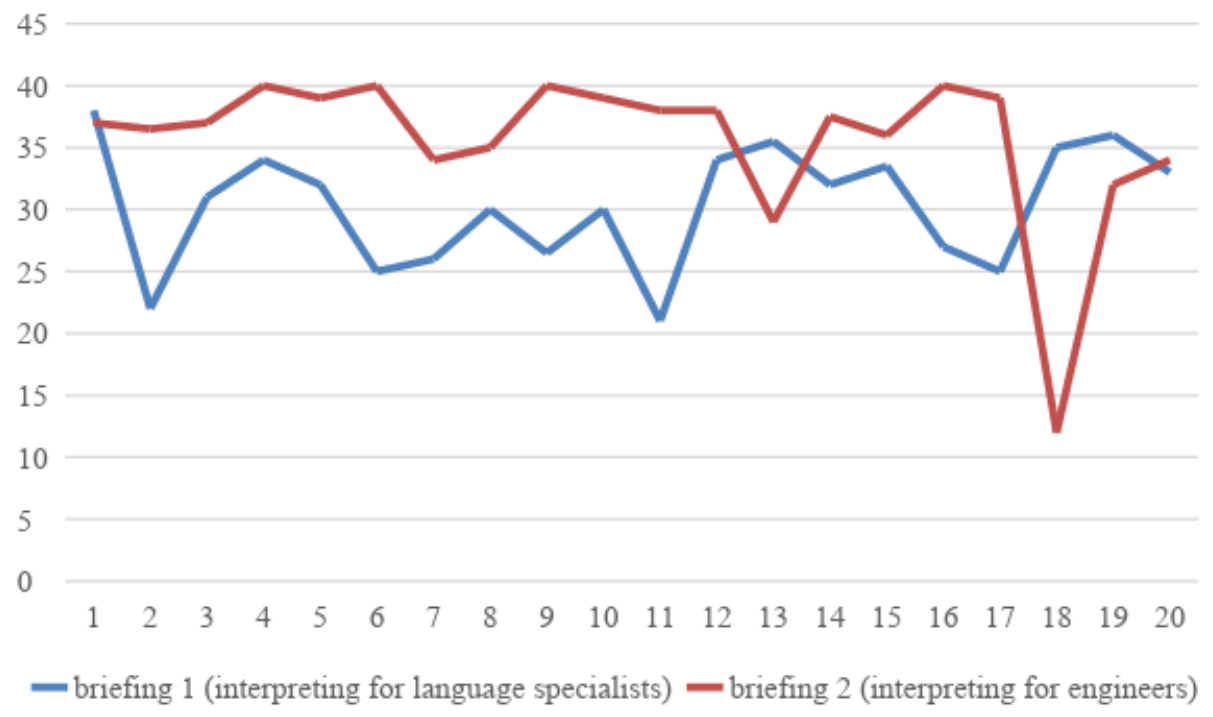

FIGURE 3: Number of correctly rendered possessives (y-axis; including omissions) from English into Polish, in the briefing 1 and briefing 2 groups ( $\mathrm{x}$-axis shows participant number; 20 in each group) 
Cases

This section presents examples of possessive use and omissions in the target text. We comment on several of them in the attempt to illustrate grammatical and lexical choices interpreters made. Each of these examples includes the original sentence as well as sample target text renditions by interpreters.

(11) This example presents a grammatical structure where the underlying subject in the infinitive clause co-refers with the subject of the higher clause.

Source sen- $\quad$ Authentic leaders are not afraid to expose their weaknesses. tence

Omission

(correct)

1. Autentyczni przywódcy nie boją się okazywać słabości.

'Authentic leaders are not afraid to expose weaknesses.'

2. Autentyczny lider nie boi się pokazać słabości.

'Authentic leader is not afraid to show weakness.'

3. Autentyczny przywódca nie boi się pokazać się od wrażliwszej strony ...

'Authentic leader is not afraid to show the weaker side'

Reflexive possessive (correct)

1. Liderzy cechujący się autentycznością nie boją się swoich słabości i tego, że ktoś je zobaczy.

'Leaders characterised by authenticity are not afraid to expose their (refl.) weaknesses and that someone will see them.'

2. Przywódca, który jest autentyczny, nie boi się okazywać swoich słabości ...

'An authentic leader is not afraid to expose his (refl.) weaknesses ...'

3. Ci przywódcy, którzy są autentyczni nie boją się swoich własnych słabości ...

'Leaders who are authentic are not afraid of their (refl.) weaknesses'

Non-reflexive possessive (incorrect)

1. Autentyczni przywódcy nie boją się okazywać ich słabości. 'Authentic leaders are not afraid to expose *their (nonrefl.) weaknesses.'

2. Autentyczny przywódca okazuje ... okazuje jego słabości. 'An authentic exposes ... exposes his (non-refl.) weaknesses.'

3. Prawdziwy przywódca nie boa się okazywać jego słabości. 'An authentic leader is not afraid to expose his (non-refl.) weaknesses.' 
Self-correction

1. Prawdziwy przywódca nie boa się okazywać jego ... Nie boi się okazywać swoich słabości.

'An authentic leader is not afraid to expose *his (nonrefl.) ... is not afraid to expose his (refl.) weaknesses.'

(12) The understood subject of the infinitival complement co-refers with the understood subject of the imperative.

Source sen- $\quad$ Do not be afraid to show your weaknesses and your fears.

tence

Omission (cor-

1. Nie można bać się okazywać lęków i słabości.

rect)

'One should not be afraid to show fears and weaknesses.'

Reflexive pos-

sessive (cor-

rect)

1. Nie bójmy się okazywać swoich lęków i słabości.

'Let us not be afraid to show our (refl.) fears and weaknesses.'

2. Nie bójcie się okazywać swoich lęków i słabości.

'Do not $\left(2^{\text {nd }}\right.$ pers. pl.) be afraid to show your (refl.) fears and weaknesses.'

3. Nie bój się okazywać swoich lęków i słabości.

'Do not ( $2^{\text {nd }}$ pers. sing.) be afraid to show your (refl.) fears and weaknesses.'

Non-reflexive

1. Nie bójmy się okazywać naszych_ęków i słabości.

'Let us not be afraid to show our (non-refl.) fears and weaknesses'

correct)

2. Nie bójcie się okazywać waszych lęków i słabości.

'Do not ( $2^{\text {nd }}$ pers.pl.) be afraid to show your (non-refl.)

fears and weaknesses'

Self-correction 1. Nie bójcie się okazywać waszych ... swoich lęków i słabości.

'Do not ( $2^{\text {nd }}$ pers.pl.) be afraid to show your (non-refl.) ... your (refl.) fears and weaknesses.'

(13) The possessive constitutes part of the direct object in this simple sentence. Its antecedent in the subject is the generally referring 'you'.

Source sen- $\quad$ You have to predict your future commitments ...

tence

Omission (cor- $\quad$ 1. Trzeba przewidzieć przyszłe zobowiązania ...

rect)

'One needs to predict future commitments ...'

2. Musimy zawsze wiedzieć, co bedziemy robić ...

'We always have to know what we are going to do ...' 
Reflexive (correct)

Non-reflexive (incorrect)

Self-correction
1. Trzeba przewidzieć swoje przyszłe zobowiązania ...

'One needs to predict one's (refl.) future commitments ...'

2. Musimy przewidywać swoje zobowiązania.

'We should predict our (refl.) commitments.'

1. Trzeba zawsze przewidzieć nasze przyszłe zobowiązania ...

'We/one needs to predict our (non-refl.) future commitments ...'

2. Musimy przewidywać nasze zobowiązania.

'We should predict our (non-refl.) commitments.'

1. Trzeba przewidywać nasze ... swoje zobowiązania.

'We/one needs to predict our (non-refl.) ... our (refl.) future commitments.'

(14) The possessive constitutes part of the direct object. Its antecedent in the subject is the generic 'people'.

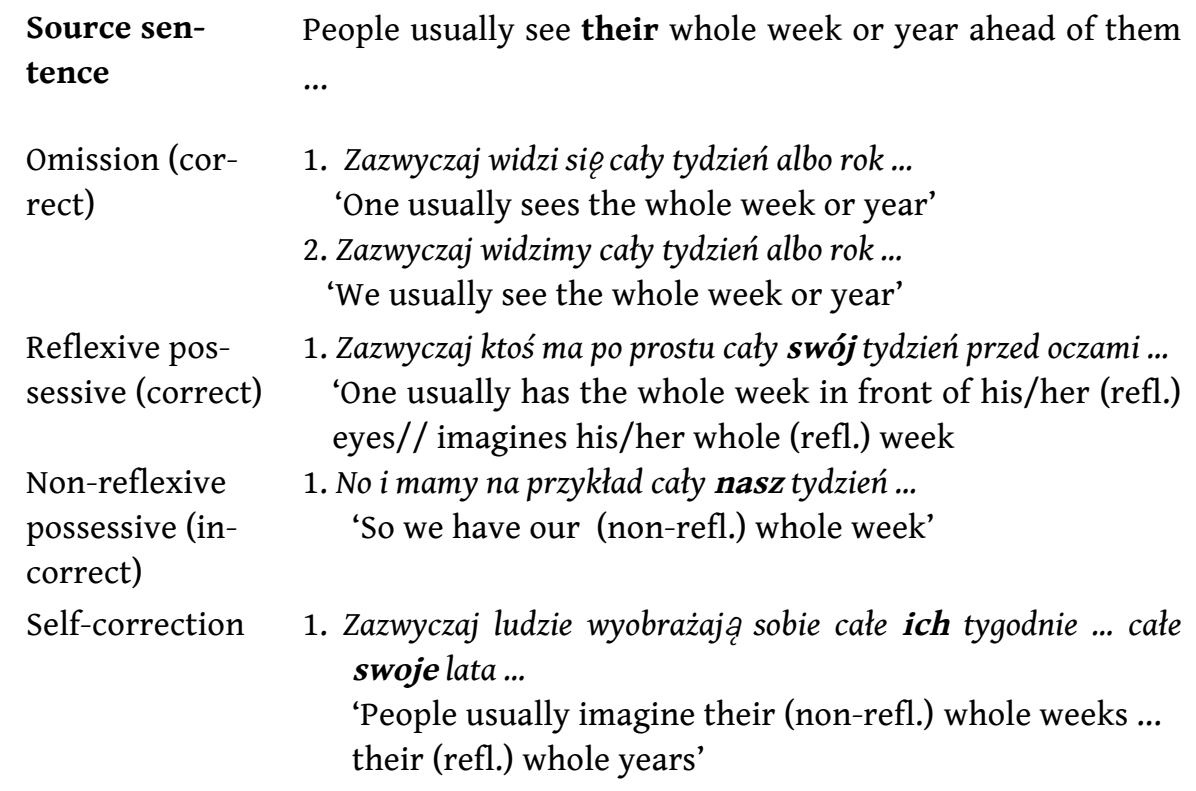

Interestingly, based on observations only (in contrast to conducting a proper statistical analysis), we also saw that structures whose subject was in the 1st person singular or plural generated frequent errors in that many informants selected the non-reflexive possessive instead of the reflexive one, e.g. in rendering (15a) into Polish, the non-reflexive was used by 5 interpreters, as in (15b). 
(15) a. (I make sure that) I am clear about my task and what I want to achieve.

b. Znam mojecele.

'I ( $1^{\text {st }}$ sing.) know my (non-refl.) goals.'

While this by itself does not constitute a clear tendency, our observation may be interesting for further research. An opinion we obtained from Centrum Języka Polskiego (the Polish Language Centre) confirmed that non-reflexive pronouns frequently occur to exemplify or underline the possession of items, or closeness to a family member, e.g. in I love my mum, or mark comparativeness, e.g. in I am feeding my dog, not yours, while they are prescriptively incorrect. The non-reflexive pronoun is used when the subject role can no longer be attributed to the possessor. This is in contrast to e.g. Russian (as described by Fabrcius-Hansen et al. 2017:17) where the non-reflexive and reflexive compete in reference to the $1^{\text {st }}$ and $2^{\text {nd }}$ person and are bound both contextually and textually.

Finally, to illustrate the extent to which the grammatical architecture of the source text was changed (which itself is a positive phenomenon in interpreting, as discussed below), we present more target text renditions of the source sentence shown in (15) a. Interpreters rendering the text that included the above sentence for language specialists (briefing 1), produced, for instance:

(15) c. Muszę zdawać sobie sprawę, jakie sq moje cele ... co chcę osiagnać, i co mam zrobić.

'I need to be aware of what my (non-refl.) goals are ... what I want to achieve and what I have to do.'

d. Muszę wiedzieć, na czym polega moje zadanie... jakie sq moje cele.

'I need to know (inf.) what my (non-refl.) task is ... and what my (nonrefl.) goals are.'

The possessive relationship is retained, yet in both cases as a modifier to the subject of a subordinate clause, in which the non-reflexive possessive is the only correct choice.

However, when the same sentence appeared (as a result of counterbalancing) in briefing 2 (interpreting for engineers), interpretations included:

(15) e. Upewniam się, że wiem, co robić i co chcę osiagnać.

'I make sure that I know what to do and what I want to achieve.'

f. Wiem, co robię i jakie sq cele.

'I know what I do and what the goals are.' 
These examples show that at least in briefing 2, meaningful items such as my goal and my task were restructured into verbal expressions such as osiagnać ('to achieve') in (15) e. In our qualitative analysis we observed that the interpreters tended to resort to deeper structural changes under briefing 2, although quantifying that tendency would call for a separate analysis.

Target text correctness rated by judges

Figure 4 presents the independent judges' ratings of the subjectively perceived quality of interpreting possessives (on a scale from 0 to 10) from English into Polish, in the two groups of participants.

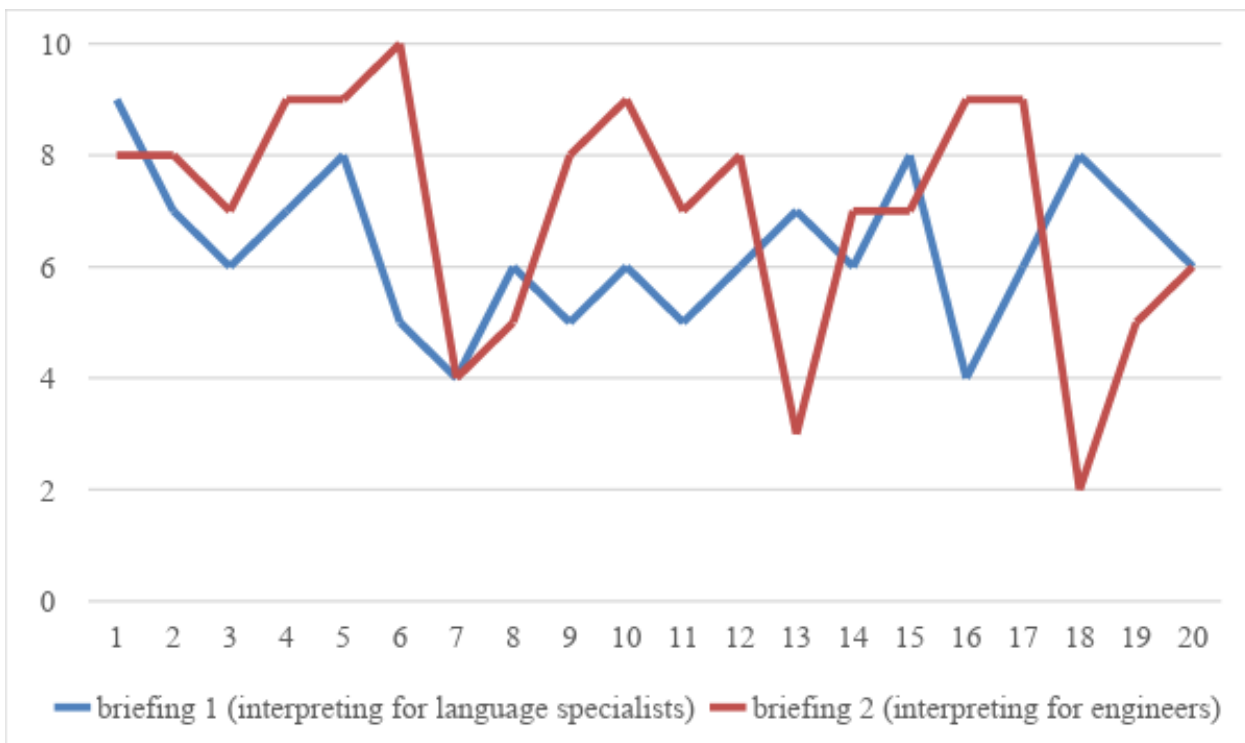

FIGURE 4: Ratings, 0-10 (the y-axis) of quality in the briefing 1 and briefing 2 groups ( $\mathrm{x}$-axis shows participant numbers 1-20 for each group)

In contrast to the associations shown above, the correlation between the type of briefing and the judges' scores did not reach the level of statistical significance for:

- $\quad$ briefing $1(\chi(1)=0.127, p=.0755)$,

- $\operatorname{briefing} 2(\chi(1)=0.214, p=.0648)$. 
Moreover, we failed to observe a statistically significant between-group difference with respect to the rating of quality of the briefing 1 group $(M=6.3 ; S D=$ $1.31)$ and the briefing 2 group $(M=7 ; S D=2.14)$.

[5] Discussion

First and foremost, data on the number of (non)reflexive possessives show that their use in Polish was less frequent than in English. While statistically insignificant (perhaps due to individual differences), a difference between the use of these possessive markers in briefing 1 and 2 was also observable. In briefing 2 , interpreters omitted the possessives more frequently than in briefing 1 , and the effect was significant. This points to possible differences in parsing under different briefings, which we discuss below.

We have found an observable number of mistakes (see Figure 1, 'incorrect renditions') committed by both target groups while interpreting. 'Mistakes', as they were referred to above, mean incorrect renditions of non-reflexive possessives when they should be rendered as reflexive possessives. There are several possible explanations of this phenomenon.

First, there could have been grammatical transfer from English, i.e. a language that does not distinguish morphologically between reflexive (subject relating, locally bound) and non-reflexive possessives. In other words, it seems plausible that the 'simpler' system was as if translated into an equivalent 'simple' system with non-reflexive possessives only. The over-representation of this correspondence in textbooks, mentioned in the introduction, may have an effect.

Furthermore, a frequency effect should also be taken into account. As seen in Table 4 below, the frequency of m. sing. swój is higher than that of jego in Polish, while other non-reflexive determiners display a higher frequency than swoja (f. sing.) and swoje (n. sing.).

High word frequency triggers faster word recognition and recall than other words in language perception and production (Smilek et al. 2014). The frequency effect, strengthened by the immediate correspondence at word level, may well be partially responsible for the errors.

In complex structures, however, erroneous renderings may have been triggered by insufficient parsing. To give an example, the experimental sentence (16a), being a complex grammatical structure, needs reformulation in Polish.

(16) a. My friend often says this helps him see his whole plan and to know the full range of his activities. 


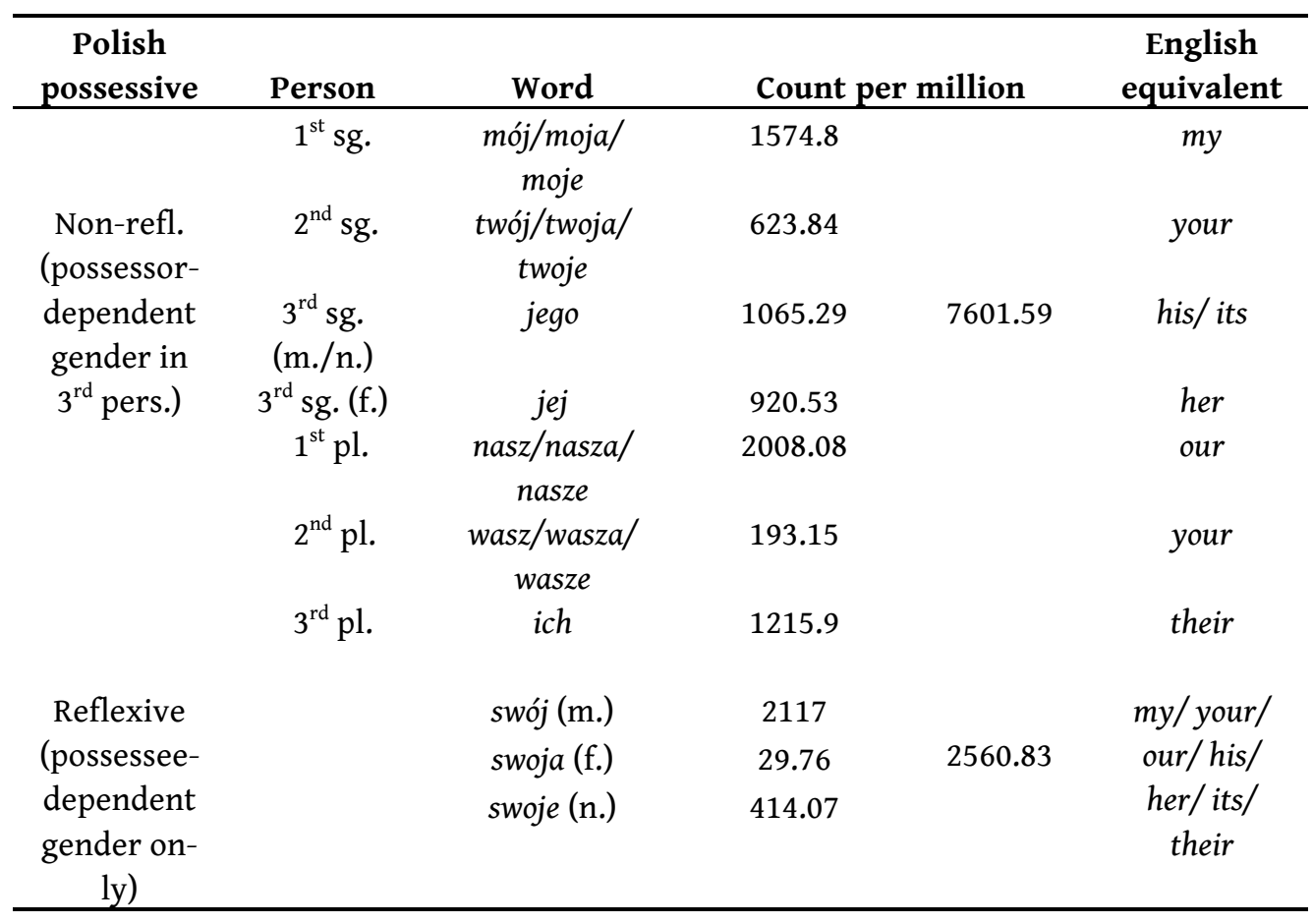

TABLE 4: Frequency of Polish non-reflexive and reflexive possessives (calculated for all cases: in Nom., Gen., Dat. Acc., Instr., Loc, Voc.)

High word frequency triggers faster word recognition and recall than other words in language perception and production (Smilek et al. 2014). The frequency effect, strengthened by the immediate correspondence at word level, may well be partially responsible for the errors.

In complex structures, however, erroneous renderings may have been triggered by insufficient parsing. To give an example, the experimental sentence (16a), being a complex grammatical structure, needs reformulation in Polish.

(16) a. My friend often says this helps him see his whole plan and to know the full range of his activities.

For instance, a correct interpretation based on deep parsing and thorough paraphrasing, given by one of the interpreters, was as follows:

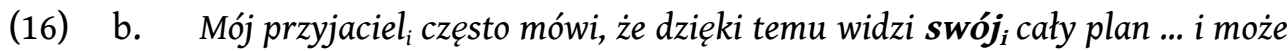
zaplanować sobie wszystkie czynności ... 
'My friend ${ }_{i}$ often says that due to that, $\left[\mathrm{he}_{\mathrm{i}}\right]$ sees ( $3^{\text {rd }}$ sg. PRES) his $\mathrm{s}_{\mathrm{i}}$ whole plan and can plan all activities.'

The interpreter's reformulation in ( 16 b.) yields a main clause structure with a $3^{\text {rd }}$ person sg. verb widzi, i.e. the subject referent is $3^{\text {rd }}$ person sg., and the reflexive correctly points back to the subject (local binding).

The following incorrect sentence was rendered by another interpreter:

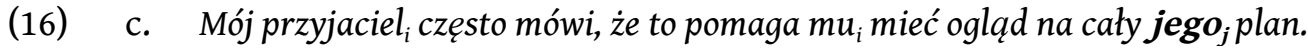

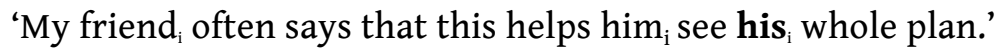

(16c) constitutes a grammatical and lexical calque. Firstly, jego in the sentence cannot point back to the subject but incorectly points to some external referent. Secondly, although to pomaga mu constitutes a correct word collocation on its own, it cannot further collocate with mieć oglad, i.e. 'to see' (literally 'to have an overview' in Polish). Two phonologically very similar verbs for English help in Polish, pomagać and pozwalać, have different selection restrictions, only the second one taking an indirect object functioning as the experiencer subject of the following verbal situation (see his plan in the sense of understanding).

Incorrect choice of verb, then, along with the wrong choice of possessive, indicates that the interpreter has not fully parsed the sentence, but transferred word-by-word. The incorrect choice of possessive strengthens this speculative explanation.

Shallow parsing, or chunking, means that only local or small grammatical structures are processed before reformulated in the target language. It involves the identification and translation of e.g. nouns as nouns, adverbs as adverbs, verbs as verbs, etc. Though shallow parsing may encompass structures bigger than single words, it triggers word-by-word translation or interpretation rather than deep restructuring. In turn, word-by-word, or horizontal processing, also referred to as transcoding, has often been observed in conference interpreters. In other words, they frequently have 'readymade' equivalents of small structures in their working languages, producing them without vertical processing.

Figure 5 presents two routes of processing in interpretation: transcoding, illustrated by means of horizontal arrows between two languages: source and target ones (SL and TL respectively), and the so-called conceptually mediated interpreting, marked with vertical arrows towards processing on the conceptual level. Christoffels' model above seems to accurately illustrate the direct connection between particular levels of processing, including grammatical pro- 
cessing, that may be related to or trigger word-by-word processing and shallow parsing. ${ }^{8}$

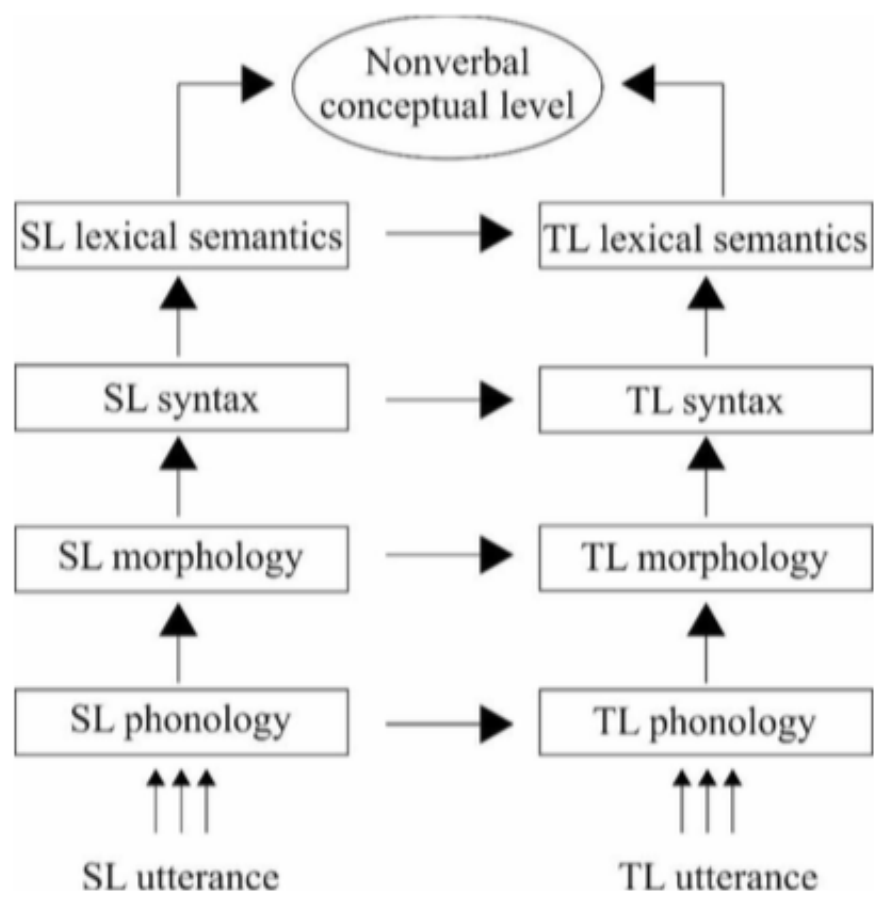

FIGURE 5: Transcoding (horizontally) and conceptually mediated (vertically) routes of processing in interpretation (after Christoffels 2004: 14)

Admittedly, erroneous renderings of locally bound possessive determiners in our data may not be explained by a single cause, especially since we used complete texts instead of isolated items for our study material, which limits the controllability of the study and makes variable manipulation less precise.

It now seems important to comment on the fact that, contrary to what was expected, interpreting accuracy was higher in briefing 2 (engineers) than briefing 1 (language specialists). While at first counterintuitive, this result is also explainable. The tasks of interpreting for language specialists vs. engineers seem to have caused different strategies, such as opting for a structurally closer rendition when the target audience specializes in language. This strategy puts more load on working memory and can easily cause more mistakes. Moreover, plain language is characteristic of technical interpreting, hence the strategy of

[8] The model represents the conceptual equivalence between a SL an a TL expression, while our discussion relates to the process of interpreting, in which the right hand arrows should point downwards. 
generating simpler sentences generated more omissions, resulting in fewer errors. While there may not be a linear correspondence between the two, it may be said that omitting the possessive simply limited the risk of making a mistake, as the reformulations did not require a choice to be made between a nonreflexive and reflexive possessive. In either case, however, our experiment has shown that the 'double' possessive system in Polish, even for native speakers of the language, is hard to get right in translation/interpretation from English.

When it comes to quality as perceived by independent judges, their scores did not align with our accuracy scores. This lack of alignment may be partially explained by the outcomes of studies conducted by Kurz (e.g. 2001), mentioned briefly at the beginning of Section 4 above. Linguistic accuracy, considered required by Pöchhacker (2001) (see Section 3 above), has turned out secondary to target language idiomaticity by the independent judges in their quality assessment, thus giving credit to Kurz's frequent observation that interpreters' generally very high expectations of accuracy do not correlate with the quality assessment of the audience.

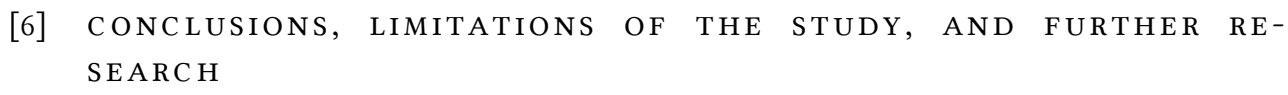

The present paper has reported on the results of an experimental study of interpreters working from English to Polish, with special attention to their (in)correct choice of possessives. The study was motivated by the fact that, in contrast to English, interpreters have to consider the syntax in choosing between the reflexive and the non-reflexive form in Polish. Correct interpretation and choice of form require awareness of structure, as choice of the reflexive is dependent on a locally bound relation between the possessive and its antecedent (subject). While our study clearly demonstrates that interpreting from a simple system into a complex system yields errors, even by native speakers of the target language, our study design cannot give us clear insights into the linguistic processing that causes such errors. We have speculated that several of the errors are due to shallow parsing. For a clearer understanding of the cognitive complexity of processing possessives in linguistically asymmetric systems, follow-up studies are needed with structurally varied sentence types tested in more controlled experiments.

However, our experiment has shown that the type of audience, as defined for the interpreter, affects the target wording. While this has resulted in fewer errors in the use of possessives for one group, the material we have collected is a rich resource that invites independent studies of other linguistic aspects to 
specify characteristics of the language chosen for the two types of audience. Such studies, however, lie outside the scope of the present paper.

\section{ACKNOWLEDGEMENTS}

We would like to express our gratitude to Centrum Języka Polskiego (Polish Language Centre) for sharing their expertise on the use of possessives in Polish.

\section{REFERENCES}

Aparicio, Xavier \& Jean-Marc Lavaur. 2018. Lexical access in trilinguals. Evidence from a double masked translation priming paradigm, Translation, Cognition and Behavior 1(1). 42-73.

Boersma, Paul and Vincent van Heuven 2001. Speak and un Speak with PRAAT, Glot International 5(9/10). 341-347.

Bühler, Hildegund. 1986. Linguistic (semantic) and extra-linguistic (pragmatic) criteria for the evaluation of conference interpretation and interpreters, Multilingua 5(4). 231-235.

Cho, Junmo and Hae-Kyeong Park. 2006. A comparative analysis of KoreanEnglish phonological structures and processes for pronunciation pedagogy in interpreter training, Théories et pratiques de la traduction et de l'interprétation en Corée 51(2). 229-246.

Christoffels, Ingrid. 2004. Cognitive studies in simultaneous interpreting. Unpublished Ph.D. dissertation, University of Amsterdam.

Comer, William. 2009. Mind the Gap: English L2 Learners of Russian and the Null Possessive Pronoun, Russian Language Journal 59. 79-99.

Fabricius-Hansen, Cathrine, Hans Petter Helland \& Anneliese Pitz. 2017. An L2 perspective on possessives: Contrasts and their possible consequences. In Cathrine Fabricius-Hansen, Bergljot Behrens, Anneliese Pitz \& Hans Petter Helland (eds), Possessives in L2 and translation: basic principles and empirical findings. (Oslo Studies in Language 9(2)). 3-41.

Gile, Daniel. 2009. Basic concepts and models for interpreter and translator training. Revised edition. Amsterdam: John Benjamins.

De Groot, Annette and Ingrid Christoffels. 2006. Language control in bilinguals. Monolingual tasks and simultaneous interpreting, Bilingualism. Language and Cognition 9(2). 189-201. 
Hartsuiker, Robert, Martin Pickering \& Eline Veltkamp. 2004. Is syntax separate or shared between languages? Cross-linguistic syntactic priming in SpanishEnglish bilinguals, Psychological Science 15. 409-414.

Helland, Hans Petter. 2017. An empirical L2 perspective on possessives: French/Norwegian, In Cathrine Fabricius-Hansen, Bergljot Behrens, Anneliese Pitz \& Hans Petter Helland (eds), Possessives in L2 and translation: basic principles and empirical findings. (Oslo Studies in Language 9(2)). 75-104.

Hervais-Adelman, Alexis, Barbara Moser-Mercer, Christoph M. Michel \& Narly Golestani. 2014. fMRI of Simultaneous Interpretation Reveals the Neural Basis of Extreme Language Control, Cerebral Cortex 25(12). 4727-4739.

Holmqvist, Kenneth, Marcus Nystrom, Richard Anderson, Richard Dewhurst, Halszka Jarodzka \& Joost van de Weiter. 2015. Eye tracking. A comprehensive guide to methods and measures. Oxford: University Press.

Ioffe, Solomon. 1985. The pronoun 'svoj' in the Russian language. Unpublished Ph.D. dissertation, University of Washington.

Kurz, Ingrid. 2001. 'Conference interpreting: Quality in the ears of the user', Meta 46(2): 394-409.

Lederer, Marianne. 1981. La traduction simultanée - expérience et théorie. Paris: Minard.

Piotr Pęzik.2012. Wyszukiwarka PELCRA dla danych NKJP. Narodowy Korpus Języka Polskiego, In Przepiórkowski, Bańko, Górski and LewandowskaTomaszczyk (eds): Narodowy Korpus Języka Polskiego [Polish National Corpus]. Wydawnictwo PWN

Pöchhacker, Franz. 2001. Quality assessment in conference and community interpreting, Meta 46(2): 410-425.

Seeber, Kilian. 2017. Multimodal Processing in Simultaneous Interpreting, In Schwieter and Ferreira (eds): The Handbook of Translation and Cognition. John Wiley \& Sons, Inc.

Smilek, Daniel, Scott Sinnett \& Alan Kingstone. 2014. Cognition. Montreal: Oxford University Press.

Stachowiak, Katarzyna. 2018. Phonology Matters in Interpreting. London: Peter Lang. 
ISO 18841:2018. Interpreting services - General requirements and recommendations.

Appendix: TeXts

Text 1: How to be a great leader?

One of the most foundational characteristics leaders possess is personal integrity. Integrity is a set of values about which you would never compromise, no matter the circumstances. My former leader in the company I worked in always said that he needs to know he has a strong handle on his values, as it is critical to the basis of loyalty. It allows people to choose their leaders.

Similar to the way in which people decide to align themselves with their favourite brands such as Nike, Starbucks, Apple, or various other companies, people look for cues that allow them to identify with their peer or superior who they would accept to extend their personal brand.

People must associate the leader with their own values; only then can they determine whether or not the leader will earn their time and trust.

In his talk, 'Make Integrity the Cornerstone of Your Leadership', General Hugh Shelton tells a story about this cornerstone value of leadership and the effects that it can have on a team.

He states that before adopting the behaviours of a leader, it's important to understand the core values of a Leader Worth Following. These leaders have a foundation of their common values that consistently guide the way they act.

I remember the leader I mentioned previously. He was a military general. He once told me that he happened to be managing a project which he at that time treated as his priority. I remember him saying: 'I had been working very hard all day long, getting "Death by PowerPoint". It was finally about 6:30 or 7 p.m. in the evening and I thought "I can't take it anymore." I just wanted to get to my bed and sleep a bit. So I took my two catalogue briefcases full of my almostmade slides and presentations that I had to watch the following day and started out of my office toward home.'

But as he walked out of his office, he saw there's a thunderstorm, and he forgot his umbrella. The driver, a young sergeant, pulled the vehicle under the overhang. He got out, saluted sharply and waited for General to get in. But the General said, 'Pete, you know the regulations prohibit me from taking a government vehicle from home to work and vice versa.' And with that he stepped into the rain, carrying his two briefcases.

The next day, the word had spread to the other employees that the General made the decision; that the General had done the right thing versus the wrong 
thing. I often wonder what message that would have sent if he had taken the car.

We watch our leaders very carefully. We take cues from the leaders' actions. We mirror similar behaviours in our lives. Possessing a great representation of integrity sets a critical foundation for your leadership.

The authentic leader is one who sets out to provide a genuine picture of who he or she is. Authentic leaders are not afraid to expose their weaknesses or to be vulnerable in some of the toughest situations. Saying 'I don't know' is real. People respond more positively to a leader with whom they can identify as being human versus someone who appears too perfect.

The behaviour of authenticity results in people who are much more willing to follow their leader through thick and thin. It makes the leader more approachable and that usually results in having a more accurate picture of their teams and state of the organization.

In 'Trust - Leading by Example', Patrick Lencioni highlights the actions of an authentic leader. The leader has to be the one that strips down and dives into that pool naked before anyone else will.

One of my great mentors, Hannah, would always say there's that moment when she wanted just to pack her things and leave her workplace but she knew she had to go on. Asked whether she feels the need not to show her struggle to her employees, she often said: 'I can see my effort and I don't mind people see it too. I am not a superhuman.'

Hannah was a great mentor, a great colleague and a great worker. She was always well prepared. She had her lively presentations, her always promising results and ... her smile. She had her problems of course, but always tried to help other people.

The truth is, people will walk through fire for a leader who is true and human. They want to know that we, as leaders know our humanity. Vulnerability on a team starts with authenticity with the team. It may be uncomfortable at times, but it is an important step to leading a strong team.

Now, imagine you are to become a leader in a big facility, let's say a Google research centre. It's your first day at work and you have to fight your fears before you even enter the building. You take a deep breath, you glance at your lucky charm and you walk in.

The key to success is not to pretend you are a superhero. Do not be afraid to show your weaknesses and your fears. People will understand that. The worst thing we can do is to hide our drawbacks and pretend we are better than everyone else. 
I have a strong feeling you will great leaders. But remember - a team is a lively spirit, with its culture and habits. With its unique members and characteristics. Every team has its own dynamics I am sure you will have your successes and your failures. Good luck then, and enjoy your chance at being great.

Text 2: How to organize your time?

This guide offers you strategies to help you plan your time effectively, encouraging you to maximise your productivity and maintain optimum control over your activities. Effective time management creates, divides and allocates time it is an active process.

First of all - plan. Planning is an essential part of being organised. You have to predict your future commitments and set aside enough time to meet them. Successful planning gives you confidence and purpose. So first read through your agenda to establish the demands that will be placed upon you. Once you have established your commitments, it might be useful to enter these on a plan or calendar.

There are several advantages to using a wall chart for this activity. People usually see their whole week or year ahead of them and are able to plan things effectively. They can see where their deadlines fall in relationship to each other.

My friend often says this helps him see his whole plan to know the full range of his activities.

If you already have plans in a calendar or diary, use these in the same way. Construct a visual image of a certain period ahead, one that you can scan quickly to refresh and review.

Now, everyone: Make filling in your plans an active process. Use colour and image to distinguish between different sorts of activities. For example, fill in deadlines in red, starting points in green. Use exclamation marks as warning signs or question marks to highlight vague commitments.

Continually review your longterm plans, assessing your achievements or adding further information as it arises.

Now, how do we proceed?

To begin taking control of our times, we will need to break it up into manageable chunks. Let's try the following strategies for planning each day a week at a time.

Let's first draw up a timetable for the week showing our days and each hour within a day. Now, we have to fill in our plans for the week ahead. This will give us a clear idea of the time we can allocate to other activities, showing us when 
we have time and how much time is available. Finally, everyone has to begin to allocate time to their other activities.

Try to fit the right tasks to the right time slots. Don't try to write a presentation in half an hour at the end of the day if you know you will be tired. Move this activity to a more suitable time when you will have the energy to complete the task. Instead, attempt more mundane tasks such as organising notes.

When planning your week, remember to balance your long-term commitments with your short term ones. Effective time management involves doing the right thing at the right time.

As each new day approaches, review your week plan to make sure that it is up to date. Make a 'to do' list for each day if this will help focus your activities. People usually like this strategy a lot, and use it to manage their weekly and long-term schedules.

I remember that I used the strategy too. It has its drawbacks (for instance, you have to spend time on planning) but it also has its advantages. I like it for its clarity, and that it makes responsible for every second you spend on something.

I had some problems at the beginning though. I found that within a week I would need to tackle more than one task at a time. I had to find a way of putting my multiple tasks in order, establishing a list of priorities. I realized I can do something I call a priority graph, and I will show you how to do during the next session. I always have my priority graph with me, and it really helps me go through my agenda.

In turn, my girlfriend told me that it is particularly important to continually review her planning strategy to make sure that it is up to date. She would have her 'revision sessions' every Friday. She always took her agenda and a glass of wine and had a look at what is still a priority and what is not.

She also told me it was important for her to find ways of motivating her mind and stimulating her thoughts when working for an extended period. She found it difficult to stay constantly active during her long-term projects but that was the way she coped with it.

That means you should always remember to avoid passive behaviour. Work actively, pursuing goals, achieving targets and reaping rewards.

I myself begin a work session by making sure that the task is achievable in the time set. I split a task that's too big into smaller tasks. Also, I make sure that I am clear about my task and what I want to achieve. Setting clear, attainable goals improves my motivation considerably.

I set a definite end point - 'I know I will have finished when...' and I also set clear rewards - 'When I have finished I will ...' 
If I have a few tasks that I don't enjoy doing, I try to do these at the beginning of my work session. I get them over and done with so that I can reward yourself with my more interesting work. Above all, I avoid putting them to the end of my 'to do' list - otherwise they will stay there forever!

Another friend of mine, Ian, makes sure that he introduces variety into his work. He avoids doing the same thing for hours on end. He breaks up long periods of activity with his quick sessions of jogging or by reviewing his objectives. He takes these opportunities to reward himself and rekindle enthusiasm.

So remember - time organization may be difficult but it's worth it. Everyone has their own way to do it and you also have to find your way of getting things done. Good luck!

CONTACTS

Katarzyna Stachowiak-Szymczak

Institute of Applied Linguistics, University of Warsaw

km.stachowiak@uw.edu.pl

Bergljot Behrens

ILOS, University of Oslo

bergljot.behrens@ilos.uio.no 